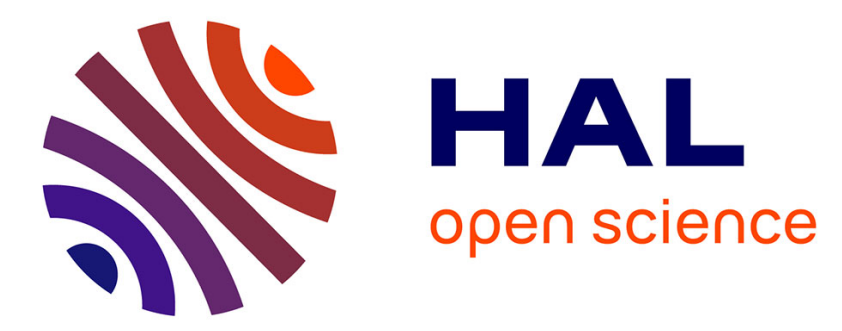

\title{
Nitrous acid in marine boundary layer over eastern Bohai Sea, China: Characteristics, sources, and implications
}

Liang Wen, Tianshu Chen, Penggang Zheng, Lin Wu, Xinfeng Wang, Abdelwahid S Mellouki, Likun Xue, Wenxing Wang

\section{To cite this version:}

Liang Wen, Tianshu Chen, Penggang Zheng, Lin Wu, Xinfeng Wang, et al.. Nitrous acid in marine boundary layer over eastern Bohai Sea, China: Characteristics, sources, and implications. Science of the Total Environment, 2019, 670, pp.282-291. 10.1016/j.scitotenv.2019.03.225 . insu-02078087

\section{HAL Id: insu-02078087 https://hal-insu.archives-ouvertes.fr/insu-02078087}

Submitted on 25 Mar 2019

HAL is a multi-disciplinary open access archive for the deposit and dissemination of scientific research documents, whether they are published or not. The documents may come from teaching and research institutions in France or abroad, or from public or private research centers.
L'archive ouverte pluridisciplinaire HAL, est destinée au dépôt et à la diffusion de documents scientifiques de niveau recherche, publiés ou non, émanant des établissements d'enseignement et de recherche français ou étrangers, des laboratoires publics ou privés. 


\section{Nitrous acid in marine boundary layer over eastern Bohai Sea,}

\section{China: characteristics, sources, and implications}

Liang Wen ${ }^{\mathrm{a}}$, Tianshu Chen ${ }^{\mathrm{a}}$, Penggang Zheng ${ }^{\mathrm{a}}$, Lin $\mathrm{Wu}^{\mathrm{a}}$, Xinfeng Wang ${ }^{\mathrm{a}, \mathrm{b}^{*}}$, Abdelwahid Mellouki ${ }^{\mathrm{a}, \mathrm{c}}$, Likun Xue ${ }^{\mathrm{a}^{*}}$, Wenxing Wang ${ }^{\mathrm{a}^{*}}$

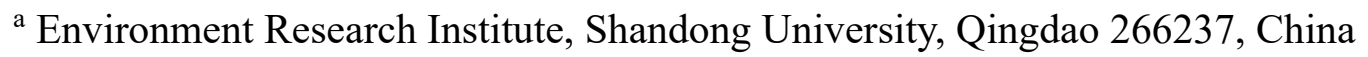

${ }^{\mathrm{b}}$ State Key Laboratory of Organic Geochemistry, Guangzhou Institute of Geochemistry, Chinese Academy of Sciences, Guangzhou 510640, China

${ }^{\mathrm{c}}$ ICARE- CNRS/OSUC, 45071 Orléans, France

${ }^{*}$ Corresponding authors. Tel.: +86-532-58631963; fax: +86-532-58631986

E-mail address: xinfengwang@sdu.edu.cn (X. Wang); xuelikun@sdu.edu.cn (L. Xue); wxwang@sdu.edu.cn (W. WANG).

\footnotetext{
Abstract

Nitrous acid (HONO) serves as a key source of hydroxyl radicals and plays important roles in atmospheric photochemistry. In this study, gaseous HONO and related species and parameters were measured in autumn of 2016 at a marine background site on Tuoji Island in eastern Bohai Sea, China. The HONO concentration in marine boundary layer (MBL) was on average $0.20 \pm 0.20 \mathrm{ppbv}$ (average \pm standard deviation) with a maximum hourly value of $1.38 \mathrm{ppbv}$. It exhibited distinct diurnal variations featuring with elevated concentrations in the late night and frequent concentration peaks in the early afternoon. During nighttime, the $\mathrm{HONO}$ was produced at a fast rate with the $\mathrm{NO}_{2}-\mathrm{HONO}$
} 
conversion rate ranging from 0.006 to $0.036 \mathrm{~h}^{-1}$. The fast HONO production and the strong dependence of temperature implied the enhancement of nocturnal HONO formation caused by air-sea interactions at high temperature. At daytime, HONO concentration peaks were frequently observed between 13:00-15:00. The observed daytime HONO concentrations were substantially higher than those predicted in the photostationary state in conditions of intensive solar radiation and high temperature. Strong or good correlations between the missing HONO production rate and temperature or photolysis frequency suggest a potential source of HONO from the photochemical conversions of nitrogen-containing compounds in sea microlayer. The source intensity strengthened quickly when the temperature was high. The abnormally high concentrations of daytime HONO contributed a considerable fraction to the primary $\mathrm{OH}$ radicals in the MBL.

Keywords: Nitrous acid, marine boundary layer, heterogeneous conversion, daytime HONO, missing HOHO source

\section{Introduction}

Nitrous acid (HONO) has been recently confirmed as an important source of hydroxyl radicals (OH radicals) (Alicke et al., 2003; Lee et al., 2013). The photolysis of $\mathrm{HONO}$ in near ultraviolet spectral region (R1) directly produces $\mathrm{OH}$ radicals which act as the most important atmospheric oxidant in troposphere during daytime (Tang et al., 2015; Wojnárovits and Takács, 2014). Because of the contribution of HONO to OH 
radicals and the subsequent influence on atmospheric oxidation capacity, the characteristics, sources, and formations, as well as the atmospheric impacts in various environments have attracted close concerns from researchers in the past decade.

Gaseous HONO comes from not only primary emissions of anthropogenic and natural sources but also secondary formations involving in $\mathrm{NO}_{\mathrm{x}}\left(\mathrm{NO}_{\mathrm{x}}=\mathrm{NO}+\mathrm{NO}_{2}\right)$ and other nitrogen-containing compounds. Previous studies have illustrated the high complexity and spatial-temporal dependence of HONO sources in troposphere. In urban and suburban areas, vehicle exhaust is considered to be an important source of HONO with emission factor of $\mathrm{HONO} / \mathrm{NO}_{\mathrm{x}}$ ratio ranging from $0.3 \%$ to $1.6 \%$ (Kurtenbach et al., 2001; Li et al., 2018; Xu et al., 2015). In farmland and forest regions, the HONO can be released from the bacteria in the presence of reactive nitrogen in the soil (Donaldson et al., 2014; Oswald et al., 2013; Su et al., 2011). During daytime, the homogeneous reaction between $\mathrm{NO}$ and $\mathrm{OH}$ radicals (R2) is known as a major formation pathway of HONO (Alicke et al., 2003). During nighttime, the heterogeneous reactions of $\mathrm{NO}_{2}$ on wet surfaces of grounds, aerosols, and artificial buildings (R3) have been identified as the main formation pathway (Finlayson-Pitts et al., 2003; Salgado and Rossi, 2002; Spataro et al., 2016; Stutz et al., 2002). The heterogeneous process of $\mathrm{NO}_{2}$ also produces particulate nitrite which serves as a potential source of HONO in conditions of high temperature, low humidity, and high acidity (R4 and R5) (Costabile et al., 2010; Wang et al., 2015). Recent studies have indicated that in many cases the observed high levels of daytime HONO cannot be explained by the above confirmed HONO sources and some new formation mechanisms have been proposed (Lee et al., 


$$
\begin{aligned}
& \mathrm{HONO}+h v \rightarrow \mathrm{NO}+\cdot \mathrm{OH}(\lambda<400 \mathrm{~nm}) \\
& \cdot \mathrm{OH}+\mathrm{NO}+\mathrm{M} \rightarrow \mathrm{HONO}+\mathrm{M} \\
& 2 \mathrm{NO}_{2}+\mathrm{H}_{2} \mathrm{O} \rightarrow \mathrm{HONO}+\mathrm{HNO}_{3} \\
& \mathrm{HONO}(\mathrm{aq}) \leftrightarrow \mathrm{HONO}(\mathrm{g}) \\
& \mathrm{HONO}(\mathrm{aq}) \leftrightarrow \mathrm{H}^{+}(\mathrm{aq})+\mathrm{NO}_{2}-(\mathrm{aq}) \\
& \mathrm{NO}_{2}+h v(\lambda>430 \mathrm{~nm}) \rightarrow \mathrm{NO}_{2}{ }^{*} \\
& \mathrm{NO}_{2}{ }^{*}+\mathrm{H}_{2} \mathrm{O} \rightarrow \mathrm{HONO}+\cdot \mathrm{OH} \\
& \mathrm{HNO}_{3} / \mathrm{NO}_{3}{ }^{-}+h v \rightarrow \mathrm{HONO} / \mathrm{NO}_{2}^{-}+\mathrm{O} \cdot(\lambda \sim 300 \mathrm{~nm})
\end{aligned}
$$

Many field measurements of HONO have been carried out in troposphere within the continents (e.g., urban, suburban, rural and remote land) (Costabile et al., 2010; Honrath et al., 2002; Su et al., 2008a; Večeřa et al., 2007; Wang et al., 2015; Xu et al., 2015); however, only a few studies were conducted in the marine boundary layer (MBL) in recent years. Zha et al (2014) measured HONO and related species and parameters at a 
coastal site along the South China Sea. They found that the nocturnal $\mathrm{NO}_{2}-\mathrm{HONO}$ conversion rates in air masses passing over sea surfaces were significantly higher than those over the land and attributed it to air-sea interactions. Wojtal et al (2011) found the temperature dependence of HONO concentrations during nighttime on Saturna Island, adjacent to the Northeast Pacific, and proposed the HONO formation in the sea microlayer (SML). In addition, Meusel et al (2016) observed abnormally high concentrations of daytime HONO with peaks in the late morning under humid conditions on the Cyprus Island in Mediterranean Sea, which was ascribed to the HONO emissions from microbial communities on soil surfaces. Reed et al (2017) and Kasibhatla et al (2018) also found daytime HONO concentration peaks during noontime on Cape Verde Island in tropical North Atlantic, whereas they attributed the daytime peaks mainly to the fast photolysis of particulate nitrates in sea salts. The above field studies have found that the fast HONO formation at nighttime or elevated HONO concentrations during daytime in MBL was linked to some specific local sources. Nevertheless, the unique characteristics of HONO in the MBL and the underlying sources require further confirmation and investigation in other marine regions.

In this study, ambient HONO concentrations and related species were measured continuously on an island located in the eastern Bohai Sea, China. We first present the concentrations and various characteristics of HONO and show the obvious nighttime and daytime concentration peaks. Then, the nighttime HONO formation and daytime concentration peaks are explored in details via case analyses and correlation analyses. Finally, the impact of daytime $\mathrm{HONO}$ on the primary source of $\mathrm{OH}$ radicals is assessed. 
This study provides some new insights into the characteristics of HONO in a polluted MBL environment in China, and proposes the role of air-sea interaction in the MBL HONO formation and atmospheric photochemistry.

\section{Experiment and Methods}

\subsection{Measurement site}

The measurement site was located on a small hill in the north of the Tuoji Island in eastern Bohai Sea, China $\left(38.19^{\circ} \mathrm{N}, 120.74^{\circ} \mathrm{E}, 153 \mathrm{~m}\right.$ a.s.1., see Fig. 1). The Tuoji Island was a small rock island $\left(7.1 \mathrm{~km}^{2}\right)$ with a large quantity of rocks and sands on the surface and a few soils in some low areas. The instruments were installed at a temperaturecontrolled monitoring station on the top floor of a four-story building. The sampling inlets were approximately $1.5 \mathrm{~m}$ above the rooftop. The measurement site was surrounded by scattered pine trees and was more than $1000 \mathrm{~m}$ far away from the residential villages and fishing piers. Thus, a rare quantity of vehicles and diminutive fishing-boats were the main local anthropogenic emission sources (Wang et al., 2014a; Zhang et al., 2016). To the west of the site, the nearest sea was located and was $160 \mathrm{~m}$ far away. The measurement site was more than $10 \mathrm{~km}$ away from the nearest major shipping route. The Tuoji Island is far away from the city regions and large industrial sources. Yantai and Dalian, two nearest cities, were situated $40 \mathrm{~km}$ to the south and 70 $\mathrm{km}$ to the north, respectively. The famous Economic Zone of Beijing-Tianjin-Hebei lied $190 \mathrm{~km}$ to the northwest. Therefore, the measurement site used in this study generally represents the marine atmospheric environment over Bohai Sea. The field 
measurements were conducted in autumn, from $5^{\text {th }}$ Oct. to $5^{\text {th }}$ Nov., 2016.

\subsection{Instrument descriptions}

A LOng Path Absorption Photometer (LOPAP, Model 03, QUMA, Germany) was deployed to continuously measure the HONO concentrations with a time resolution of 30 s. Ambient gaseous HONO was absorbed simultaneously by sulphanilamidehydrochloric acid reagent in double tandem glass spiral tubes equipped in an outdoor sampling unit under a constant temperature of $20^{\circ} \mathrm{C}$. More than $99 \%$ of HONO could be collected in the front coil (Kleffmann and P.Wiesen, 2008). The back spiral tube was used to obtain the interference signal caused by other nitrogen compounds in sampling tubes. The absorption solutions through both two spiral tubes were pumped into the instrument and converted to colored azo dye after mixed with $\mathrm{N}$ naphtylethylendiamine-dihydrochloride reagent (Kleffmann et al., 2006). Then, the absorption spectra of these two mixed reagents were measured in two long path absorption tubes with two spectrometers. The raw aqueous concentrations of HONO in the two channels were calculated based on the regular detection of background signal with high-purity nitrogen every 12 hours and the routing calibration by using nitrite standard solution every four days. The HONO concentration in ambient air was finally obtained from the aqueous concentration difference between the two channels and the flow rates of air sample and absorption solution. The detection limit and the uncertainty of the LOPAP were $0.2 \mathrm{ppt}$ and $10 \%$, respectively. Refer to Li et al. (2018) for detailed descriptions of the operation and quality assurance and quality control procedures. 
In addition, relevant pollutants and parameters were measured concurrently with online instruments. Specifically, NO was monitored by a chemiluminescence instrument (Model 42C, Thermo Electron Corporation, USA). $\mathrm{NO}_{2}$ was analyzed by a cavity attenuated phase shift spectroscopy (Model T500U, API, USA). Ozone was measured by a two-path UV photometric analyzer (Model 49, Thermo Electron Corporation, USA). CO was detected by a non-dispersive infrared analyzer (Model 300EU, API, USA). The photolysis frequency of $\mathrm{NO}_{2}$ represented by $\mathrm{J}_{\left(\mathrm{NO}_{2}\right)}$ was quantified by a filter radiometer (Model 2-pi-JNO 2 , Meteorologie Consult, Germany). Meteorological parameters including temperature (T), relative humidity (RH), wind speed (WS) and wind direction (WD) were obtained from an automatic meteorological station (Model PC-4, Jinzhou Sunshine, China). Detailed information of these instruments can be seen in previous studies (Sun et al., 2016; Wang et al., 2014b; Wang et al., 2012; Xue et al., 2014).

\subsection{Photostationary state calculation}

To assist to understand the observed daytime peaks of HONO, photostationary state (PSS) was assumed during the periods from 9:00 to 15:00 in conditions of strong solar radiation when a balance was achieved quickly between the production and loss due to the fast reaction rates. The PSS HONO concentration (HONOpss) was calculated via Eq. (1) with consideration of only one major source of homogeneous formation ( $S_{G a s,}$, $\mathrm{R} 2$ ) and three loss pathways of photolysis ( $\left.L_{P h o t o l y s i s}, \mathrm{R} 1\right)$, reaction with $\mathrm{OH}$ radical ( $L_{\text {Gas }}$, R9), and dry deposition (LDeposition) (Lee et al., 2016). Here, [NO] represents the in-situ 
measured NO concentration. The values of $J(H O N O)$ and $J\left(O^{I} D\right)$ were estimated based on the relationships between the data of $J(H O N O)$ and $J\left(O^{I} D\right)$ from an Actinic Flux spectrometer (Model 2-pi-actinic-flux spectrograph, Meteorologie Consult, Germany) and the data of $\mathrm{J}\left(\mathrm{NO}_{2}\right)$ from a filter radiometer in our previous comparative experiment. $[\mathrm{OH}]$ was estimated with an improved empirical formula of $E q$. (2) with $\mathrm{NO}_{2}$ and HONO concentrations together with $\mathrm{NO}_{2}, \mathrm{O}_{3}$, and $\mathrm{HONO}$ photolysis frequencies (Alicke et al., 2002). The calculated $\mathrm{OH}$ concentration was in the range of 0.1 to $8.6 \times 10^{6}$ molecules $\mathrm{cm}^{-3}$, which was a little lower than the measured range during the same daytime period in summer at a suburban site in North China (Lu et al., 2013). The deposition velocity of HONO ( VHONO$_{\text {) }}$ was set as $0.005 \mathrm{~m} \mathrm{~s}^{-1}$ according to previous studies (Michoud et al., 2014; Stutz et al., 2002). The height of the boundary layer $(h)$ was adopted from the European Centre for Medium-Range Weather Forecasts

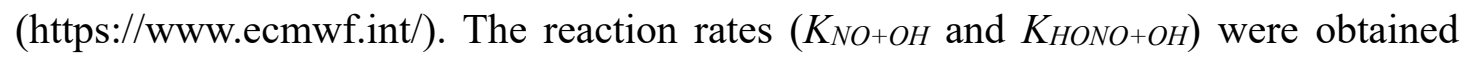
from the Task Group on Atmospheric Chemical Kinetic Data Evaluation (http://iupac.pole-ether.fr/index.html). Note that the heterogeneous $\mathrm{NO}_{2}$ reactions on aerosol surfaces and the photo-enhanced surface reactions of $\mathrm{NO}_{2}$ were not considered in the PSS calculation due to the relatively small contributions to the daytime HONO formation. The estimated average HONO formation rate from heterogeneous reactions of $\mathrm{NO}_{2}$ on aerosol surfaces during daytime was less than $1 \%$ compared to the $\mathrm{HONO}$ production rate in the PSS period according to the assumptive uptake coefficient of $10^{-}$ ${ }^{6}$, the particulate surface concentration of $2.3 \times 10^{-4} \mathrm{~m}^{2} \mathrm{~m}^{-3}$, and the molecular speed of $223 \mathrm{~m} \mathrm{~s}^{-1}$. The photo-enhanced surface reactions of $\mathrm{NO}_{2}$ contributed approximately 


$$
\begin{gathered}
\mathrm{HONO}+\mathrm{OH} \rightarrow \mathrm{NO}_{2}+\mathrm{H}_{2} \mathrm{O} \\
{[\mathrm{HONO}]_{P S S}=\frac{\mathrm{S}_{\text {Gas }}}{L_{\text {Gas }}+L_{\text {Photolysis }}+L_{\text {Deposition }}}=\frac{[\mathrm{NO}] *[\mathrm{OH}]^{*} k_{\mathrm{NO}+\mathrm{OH}}}{[\mathrm{OH}]^{*} k_{\mathrm{OH}+\mathrm{HONO}}+J(\mathrm{HONO})+\frac{v_{\mathrm{HONO}}}{h}}} \\
{[\mathrm{OH}]=4.1 * 10^{9} * \frac{\mathrm{J}\left(\mathrm{O}^{1} \mathrm{D}\right)^{0.83} * J\left(\mathrm{NO}_{2}\right)^{0.19} *\left(140 * \mathrm{NO}_{2}+1\right)+\mathrm{HONO} * \mathrm{~J}(\mathrm{HONO})}{0.41 * \mathrm{NO}_{2}{ }^{2}+1.7 * \mathrm{NO}_{2}+1+\mathrm{NO}^{*} k_{\mathrm{NO}+\mathrm{OH}}+\mathrm{HONO}^{*} k_{\mathrm{HONO}+\mathrm{OH}}}}
\end{gathered}
$$

\section{Results and discussion}

\subsection{Concentrations and temporal variations}

The HONO concentrations in MBL over eastern Bohai Sea in autumn were relatively high. Table 1 and Fig. 2 show the statistical results and time series of the concentrations of HONO, related species as well as meteorological parameters during the measurement period. As shown, the average HONO mixing ratio was $0.20 \pm 0.20$ ppbv (average \pm standard deviation). The maximum hourly HONO concentration was as high as 1.38 ppbv, appearing at 14:00 local time (LT) on $14^{\text {th }}$ October. The maximum one-minute value was even higher, reaching $1.90 \mathrm{ppbv}$. The precursor $\mathrm{NO}_{2}$ was at a moderately high level, with an average concentration of $5.3 \pm 4.1 \mathrm{ppbv}$. The average NO and CO concentrations were $0.5 \pm 0.7$ and $484 \pm 271 \mathrm{ppbv}$, respectively, indicating a minor influence from local anthropogenic sources including exhausts of vehicles, boats, and ships. Ozone, another important source of hydroxyl radicals, appeared in moderate concentrations with an average value of $40 \pm 14 \mathrm{ppbv}$. When compared to other locations, 

227 possibly quite fast.

the HONO concentrations observed over eastern Bohai Sea were lower than those in inland urban areas in Bohai Rim region (Hendrick et al., 2014; Li et al., 2018; Wang et al., 2015), but higher than those in clean marine areas in Mediterranean and tropical North Atlantic (Kasibhatla et al., 2018; Meusel et al., 2016).

The HONO concentrations over the eastern Bohai Sea in autumn exhibited large temporal variations. Particularly, the HONO concentrations in the early period (from $5^{\text {th }}$ to $21^{\text {th }}$ Oct.) were much higher than those in the later period (from $22^{\text {th }}$ Oct. to $5^{\text {th }}$ Nov.). During the early period, the average HONO concentration was $0.27 \pm 0.23 \mathrm{ppbv}$ (also included in Table 1), with a maximum hourly value of 1.38 ppbv. In comparison, during the later period, the average HONO concentration was $0.13 \pm 0.11 \mathrm{ppbv}$ and the maximum hourly value was only $0.53 \mathrm{ppbv}$. In addition, the average $\mathrm{HONO} / \mathrm{NO}_{\mathrm{x}}$ ratio of 0.057 in the early period was much higher than the ratio of 0.021 in the later period, which means that more HONO was produced in the earlier period than in later period. With examination of related species and meteorological parameters, we find that the concentrations of $\mathrm{NO}_{2}, \mathrm{NO}$, and $\mathrm{CO}$, the winds, and the air masses were comparable in the two periods, while the ambient temperature and photolysis rate of $\mathrm{NO}_{2}$ in the early period were higher than those in the later period. It indicates that the HONO formation in the early period in conditions of high temperature and intensive solar radiation was

To further investigate the causes of the HONO variations, we compared the diurnal patterns of HONO and related pollutants and parameters in the two periods (see Fig. 3). Overall, HONO exhibited distinct diurnal variation with two concentration peaks at 
nighttime and daytime. The nighttime peak appeared in the late night and the daytime peak occurred around 14:00 LT in the early afternoon. During nighttime, the average peak concentration of $\mathrm{HONO}$ in the early period was approximately 1.5 times as high as that in the later period ( 0.37 vs. $0.25 \mathrm{ppbv})$. Nevertheless, during daytime, the average concentration peak in the early period was up to 3 times as high as that in the later period ( 0.39 vs. $0.13 \mathrm{ppbv})$. Moreover, at daytime, the average peak value of $\mathrm{HONO} / \mathrm{NO}_{\mathrm{x}}$ ratio in the early period was 4.9 time as high as that in the later period (0.127 vs. 0.026$)$. Note that the diurnal patterns and concentrations of $\mathrm{NO}_{2}$ and $\mathrm{NO}$ in the two periods were quite similar, while the temperature and photolysis rate at daytime were significantly higher than those in the later period. The above results suggest that in the early period HONO was produced at very fast rates especially at daytime, which may be linked to the temperature and intensive-sunlight conditions and led to rather high levels of daytime HONO in this period.

\subsection{Nocturnal HONO formation}

In order to obtain a deep understanding of the nighttime HONO formation in MBL, the cases with significant HONO production at nighttime were selected and analyzed in details. The nocturnal cases were identified following the below four criteria: (1) only the data during nighttime (18:00 - 6:00 LT in the next morning) were considered and used; (2) both $\mathrm{HONO}$ concentration and $\mathrm{HONO} / \mathrm{NO}_{2}$ ratio increased continuously for more than two hours; (3) the air mass kept unchanged with small wind speed, stable wind direction, and stable CO concentrations; (4) the concentration of the precursor 
$\mathrm{NO}_{2}$ had minor change during the selected periods. Finally, eight nocturnal cases (i.e., $6^{\text {th }}, 8^{\text {th }}, 9^{\text {th }}, 13^{\text {th }}-14^{\text {th }}, 23^{\text {th }}, 25^{\text {th }}-26^{\text {th }}, 30^{\text {th }}$ Oct. and $3^{\text {rd }}$ Nov.) were selected and the $\mathrm{NO}_{2}-$ HONO conversion rate ( $\left.C_{H O N O}\right)$ were calculated via $E q$. (3) (see Fig. 4 and Table 2).

$$
C_{\mathrm{HONO}}=\frac{[\mathrm{HONO}]_{t_{2}}-[\mathrm{HONO}]_{t_{1}}}{\overline{N O_{2}} *\left(t_{2}-t_{1}\right)}
$$

As shown, the continuous increase in HONO concentrations mostly occurred immediately after sunset (i.e., after 18:00) and sometimes started in the late night (after 22:00). During the periods for two to five hours, the HONO concentration had increased by 0.13 to $1.07 \mathrm{ppbv}$ and the increase in HONO concentrations exhibited positive correlation with the $\mathrm{NO}_{2}$ concentration. The nocturnal heterogeneous $\mathrm{NO}_{2}-\mathrm{HONO}$ conversion rate ranged from 0.006 to $0.036 \mathrm{~h}^{-1}$, with an average value of $0.018 \mathrm{~h}^{-1}$. The maximum $C_{H O N O}$ of $0.036 \mathrm{~h}^{-1}$ appeared in the midnight of $13^{\text {th }}$ Oct., featuring with high temperature (on average $18.8^{\circ} \mathrm{C}$ ) as well as continuous northerly wind. The $\mathrm{NO}_{2}$-toHONO conversion rates at nighttime over the eastern Bohai Sea were obviously higher than the average rate range of $0.003-0.010 \mathrm{~h}^{-1}$ at inland sites in the Bohai Rim Region in previous studies (Li et al., 2018; Wang et al., 2017; Wang et al., 2015; Zhang et al., 2019). The facilitated $\mathrm{NO}_{2}$-to-HONO conversion observed in the MBL in this study was consistent with that found at a coastal site in South China when the air mass came from the marine region and was ascribed to the air-sea interactions (Zha et al., 2014). The nocturnal $\mathrm{NO}_{2}-\mathrm{HONO}$ conversion rate in $\mathrm{MBL}$ over eastern Bohai Sea varied with atmospheric conditions. Correlation analysis shows a strong positive linear relationship between $C_{H O N O}$ and the ambient temperature $(\mathrm{R}=0.94, p<0.01)$. For the selected eight nighttime cases, when the temperature was above $15^{\circ} \mathrm{C}$ the $C_{\text {HONO }}$ was 
higher than or equal to $0.02 \mathrm{~h}^{-1}$, while they were all lower than $0.02 \mathrm{~h}^{-1}$ when the temperature was below $15^{\circ} \mathrm{C}$ (see Table 2). Nevertheless, $C_{H O N O}$ exhibited a moderate correlation with relative humidity $(\mathrm{R}=0.57, p<0.01)$. The above results indicate that the nocturnal $\mathrm{HONO}$ formation from $\mathrm{NO}_{2}$ over eastern Bohai Sea was enhanced at high temperature. It is consistent with the finding by Wojtal et al. (2011) that the HONO production from $\mathrm{NO}_{2}$ on seawater surface was largely influenced by the temperature.

\subsection{Daytime HONO concentration peaks and the missing source}

Daytime concentration peaks of HONO were frequently observed in the MBL over eastern Bohai Sea. Figure 5 shows four daytime cases with apparent HONO concentration peaks and stable weather conditions (i.e., sunny, low wind speed, stable wind direction, and stable $\mathrm{CO}$ concentration). The daytime concentration peaks of HONO frequently exceeded $0.4 \mathrm{ppbv}$ and the maximum 1-minute value reached 1.90 ppbv. The daytime HONO concentration usually started to increase immediately after the solar radiation getting strong and when the temperature was relatively high (approximately above $15^{\circ} \mathrm{C}$ ). The HONO concentration reached the maximum in the early afternoon (13:00-15:00 LT) after which period the temperature and solar radiation started to drop quickly. Such high concentration peaks of daytime HONO in the presence of intensive solar radiation were rarely observed in other marine regions (Kasibhatla et al., 2018; Meusel et al., 2016). The daytime HONO concentration peaks in the early afternoon observed in this study are different from the daytime peaks appeared in the late morning and noon in the previous studies in other marine areas 
(Kasibhatla et al., 2018; Meusel et al., 2016). The morning peaks of HONO on the Cyprus Island in Mediterranean Sea were caused by the microbial activities on soil surface after sunrise (Meusel et al., 2016), while the noon peaks on Cape Verde Island in tropical North Atlantic were associated with the photolysis of particulate nitrates in the presence of intense solar radiation (Kasibhatla et al., 2018). The rock dominated surface of the small Tuoji Island together with the unmatched concentration peaks of HONO and NO suggests that microbial activities had little influence on the measured daytime HONO.

With the deployment of PSS calculations for the selected four daytime cases, the observed daytime HONO peaks were obviously higher than the PSS prediction, in particular when the ambient temperature was relatively high (also shown in Fig. 5). During 9:00-15:00 on $10^{\text {th }}$ and $14^{\text {th }}$ October, the temperature was always above $15^{\circ} \mathrm{C}$ and the observed HONO concentrations were more than two times as high as the PSS calculated values. Whereas, on $6^{\text {th }}$ October and $4^{\text {th }}$ November, the temperature began to exceed $15^{\circ} \mathrm{C}$ around the noon and higher HONO observation than PSS prediction only appeared in the early afternoon. In the morning of these two days, the PSS calculated HONO generally matched the observed values. The high daytime concentration peaks of HONO in MBL over eastern Bohai Sea suggest the existences of important missing sources during daytime and the intensity of missing sources was related to the ambient temperature.

Correlation analysis using all the data during the PSS periods further confirmed the dependence of the missing HONO source rate (S(HONO-missing), Eq (4)) to the ambient 
temperature. As shown in Fig. 6, the missing production rate of $\mathrm{HONO}$ at daytime exhibited nearly exponential increase with the temperature $(\mathrm{R}=0.69)$. When the temperature was below $15^{\circ} \mathrm{C}$, the missing $\mathrm{HONO}$ source rate was small and changeless. Once the temperature was above $15^{\circ} \mathrm{C}$, the missing production rate sharply increased with the temperature and was as high as $2 \mathrm{ppbv} \mathrm{h}^{-1}$ when the temperature reached 22 ${ }^{\circ} \mathrm{C}$. In addition, a rising trend was also found in the missing production rate of $\mathrm{HONO}$ as the photolysis frequency of $\mathrm{NO}_{2}$ increased (also see Fig. 6). In comparison, no apparent correlation was found between the values of $S\left(H O N O_{-m i s s i n g}\right)$ and the humidity, $\mathrm{NO}_{2}$ concentrations, or the products of $\mathrm{NO}_{2} * \mathrm{~J}\left(\mathrm{NO}_{2}\right)$. The above results indicate that the missing sources of daytime HONO were likely light-induced reactions of nitrogencontaining compounds (e.g., nitrates and nitric acid) on sea surfaces and that the source intensity was largely influenced by ambient temperature. As reported by Goldstein and Rabani (2007) and Yang et al (2018) in laboratory studies, the photolysis of dissolved nitrates produced nitrites at a fast rate which could release gas-phase HONO when the temperature was relatively high. Therefore, the abnormal daytime concentration peaks of HONO observed in the MBL over eastern Bohai Sea might be attributed to an unnoticed source of photolysis of nitrates (or other nitrogen-containing compounds) in the SML and the subsequent HONO release at relatively high temperature. Future laboratory or field studies are required to evaluate the accurate production rate of HONO from photolysis of nitrates in SML on sea surface and the contribution to the daytime HONO.

$$
S\left(\mathrm{HONO}_{- \text {missing }}\right)=\left([\mathrm{HONO}]_{\text {Meas }}-[\mathrm{HONO}]_{P S S}\right) *\left([\mathrm{OH}] * k_{O H+H O N O}+J(\mathrm{HONO})+\frac{v_{H O N O}}{h}\right)
$$




\subsection{Impact of daytime HONO on the primary source of $\mathrm{OH}$ radicals}

341 The high daytime HONO concentrations observed over the eastern Bohai Sea 342 probably pose a significant impact on the $\mathrm{OH}$ radicals through photolysis. Here, we compare the production rate of $\mathrm{OH}$ radicals from $\mathrm{HONO}$ photolysis and ozone photolysis, which are well known as two major primary sources of $\mathrm{OH}$ radicals. The net production rate of $\mathrm{OH}$ radicals from $\mathrm{HONO}$ photolysis $\left(\mathrm{P}(\mathrm{OH})_{\text {HONO net }}\right)$ was estimated via Eq. (5) (Su et al., 2008b). The $\mathrm{OH}$ production rate from ozone photolysis $\left(\mathrm{P}(\mathrm{OH})_{\mathrm{O}_{3}}\right.$, only from the $\mathrm{O}^{1} \mathrm{D}$ branch) was calculated by $E q$. (6) (Su et al., 2008b). The involved reaction rate constants were adopted from the Task Group on Atmospheric Chemical Kinetic Data Evaluation of IUPAC (http://iupac.pole-ether.fr/index.html).

$$
\begin{aligned}
& P(O H)_{H O N O n e t} \\
& =J(H O N O) *[H O N O]-k_{O H+N O} *[O H] *[N O]-k_{O H+H O N O} *[O H] *[H O N O] \\
& P(O H)_{O_{3}}=\frac{2 * J\left(O^{1} D\right) *\left[O_{3}\right]^{*} k_{O^{1} D+H_{2} O}}{k_{O^{1} D+H_{2} O}+k_{O^{1} D+M}}
\end{aligned}
$$

350 As shown in Fig. 7, during the periods of 9:00-15:00 in the four daytime cases, the net production rate of $\mathrm{OH}$ radicals from $\mathrm{HONO}$ photolysis ranged from below zero to several ppbv $\mathrm{h}^{-1}$. The maximum hourly production rate of net $\mathrm{OH}$ radicals reached 4.1

$353 \mathrm{ppbv} \mathrm{h}^{-1}$, contributing to approximately $49.6 \%$ of the total primary production of $\mathrm{OH}$ 354 radicals from both $\mathrm{HONO}$ and ozone photolysis. This maximum net production rate and maximum contribution caused by daytime HONO appeared in the early afternoon of $14^{\text {th }}$ October, when both HONO concentration and ambient temperature were the highest during the measurement period. Nevertheless, under the conditions of relatively 
low temperature, the contributions from HONO photolysis were relatively small or even negligible. Overall, the elevated concentrations of daytime HONO over the eastern Bohai Sea at high temperature provided a considerable contribution to the primary source of $\mathrm{OH}$ radicals and subsequently to a certain degree enhanced the atmospheric oxidation capacity.

\section{Conclusions}

To understand the characteristics of ambient HONO and its sources and formation mechanisms in a marine region adjacent to the polluted North China, field measurements of $\mathrm{HONO}$ and related parameters were conducted from $5^{\text {th }}$ Oct. to $5^{\text {th }}$ Nov. in 2016 at a marine background site on Tuoji Island in the eastern Bohai Sea. Moderately high concentrations of HONO were observed, with the maximum hourly value of $1.38 \mathrm{ppbv}$. The HONO concentration displayed apparent temporal variation and concentration peaks frequently occurred both in the later night and in the early afternoon. During nighttime, HONO was produced quickly from heterogeneous reactions of $\mathrm{NO}_{2}$ and the conversion rates were obviously higher than those at inland sites in the Bohai Rim Region. The fast heterogeneous formation of HONO at nighttime was mainly caused by air-sea interactions and was facilitated by the relatively high temperature. During the daytime, the HONO concentration peaks usually appeared in early afternoon in conditions of strong photolysis frequency and high temperature. The photochemical conversions of nitrogen-containing compounds in SML together with the subsequent HONO release under the condition of high temperature were likely to 
380

381

382

383

384

385

386

387

388

389

390

391

392

393

394

395

396

397

398

399

400

401

be an important source for the abnormally high daytime HONO. The photolysis of daytime HONO provided a considerable contribution to the primary source of $\mathrm{OH}$ radicals and thus should be fully considered in modeling simulations of air quality and atmospheric chemistry.

\section{Acknowledgement}

This work was supported by the National Natural Science Foundation of China (No.:

41505111, 91544213, and 41675118), the National Key Research and Development Program of China (No.: 2016YFC0200500), Marie Skłodowska-Curie actions (H2020MSCARISE-2015-690958), the Qilu Youth Talent of Shandong University, and the State Key Laboratory of Organic Geochemistry, GIGCAS (Grant No. SKLOG-201616).

\section{References}

Alicke, B., Geyer, A., Hofzumahaus, A., Holland, F., Konrad, S., Patz, H.W., et al., 2003. OH formation by HONO photolysis during the BERLIOZ experiment. J. Geophys.Res. 108.

Alicke, B., Platt, U., Stutz, J., 2002. Impact of nitrous acid photolysis on the total hydroxyl radical budget during the Limitation of Oxidant Production/Pianura Padana Produzione di Ozono study in Milan. J. Geophys.Res. 107.

Costabile, F., Amoroso, A., Wang, F,. 2010. Sub- $\mu$ m particle size distributions in a suburban Mediterranean area. Aerosol populations and their possible relationship with HONO mixing ratios. Atmos. Environ. 44, 5258-5268.

Donaldson. M.A., Bish, D.L., Raff, J.D., 2014. Soil surface acidity plays a determining role in the 
Finlayson-Pitts, B.J., Wingen, L.M., Sumner, A.L., Syomin, D., Ramazan, K.A. 2003. The heterogeneous hydrolysis of $\mathrm{NO}_{2}$ in laboratory systems and in outdoor and indoor atmospheres: An integrated mechanism. Phys. Chem. Chem. Phys. 5, 223-242.

406

407

George, C., Beeldens, A., Barmpas, F., Doussin, J-F., Manganelli, G., Herrmann, H., et al., 2016. Impact of photocatalytic remediation of pollutants on urban air quality. Frontiers of Environmental Science \& Engineering 10.

Goldstein, S., Rabani, J., 2007. Mechanism of Nitrite Formation by Nitrate Photolysis in Aqueous Solutions: The Role of Peroxynitrite, Nitrogen Dioxide, and Hydroxyl Radical. Chem. Soc. 129, 10597-10601.

Hendrick, F., Müller, J-F., Clémer, K., Wang, P., Mazière, M.D., Fayt, C., et al., 2014. Four years of ground-based MAX-DOAS observations of $\mathrm{HONO}$ and $\mathrm{NO}_{2}$ in the Beijing area. Atmos. Chem. Phys. 14, 765-781.

Honrath, R.E., Lu, Y., Peterson, M.C., Dibb, J.E., Arsenault, M.A., Cullen, N.J., et al., 2002. Vertical fluxes of $\mathrm{NO}_{x} ; \mathrm{HONO}$, and $\mathrm{HNO}_{3}$ above the snowpack at Summit, Greenland. Atmos. Environ. 36: $2629-2640$.

Karamchandani, P., Emery, C., Yarwood, G., Lefer, B., Stutz, J., Couzo, E., et al., 2015. Implementation and refinement of a surface model for heterogeneous HONO formation in a 3-D chemical transport model. Atmos. Environ. 112: 356-368.

Kasibhatla, P., Sherwen, T., Evans, M.J., Carpenter, L.J., Reed, C., Alexander, B., et al., 2018. Global impact of nitrate photolysis in sea-salt aerosol on $\mathrm{NO}_{x}, \mathrm{OH}$, and $\mathrm{O}_{3}$ in the marine boundary layer. Atmos. Chem. Phys. 18, 11185-11203. 
Kleffmann, J., Lörzer, J.C., Wiesen, P., Kern, C., Trick, S., Volkamer, R., et al., 2006. Intercomparison of the DOAS and LOPAP techniques for the detection of nitrous acid (HONO). Atmos. Environ. $40,3640-3652$.

Kleffmann, J., Wiesen, P., 2008, Technical Note: Quantification of interferences of wet chemical HONO LOPAP measurements under simulated polar conditions. Atmos. Chem. Phys. 8, 6813-6822.

Kurtenbach, R., Becker, K.H., Gomes, J.A.G., Kleffmann, J., Lorzer, J.C., Spittler, M., et al., 2001. Investigations of emissions and heterogeneous formation of HONO in a road traffic tunnel. Atmos. Environ. 35, 3385-3394.

Laufs, S., Kleffmann, J., 2016. Investigations on $\mathrm{HONO}$ formation from photolysis of adsorbed $\mathrm{HNO}_{3}$ on quartz glass surfaces. Phys. Chem. Chem. Phys. 18, 9616-9625.

Lee, B.H., Wood, C., Herndon, S.C., Lefer, B.L., Luke, W.T., Brune, W.H., et al., 2013. Urban measurements of atmospheric nitrous acid: A caveat on the interpretation of the HONO photostationary state. J. Geophys.Res. Atmospheres 118, 12274-12281.

Lee, J.D., Whalley, L.K., Heard, D.E., Stone, D., Dunmore, R.E., Hamilton, J.F., et al., 2016. Detailed budget analysis of HONO in central London reveals a missing daytime source. Atmos. Chem. Phys. 16, 2747-2764.

Legrand, M., Preunkert, S., Frey, M., Bartels-Rausch, T., Kukui, A., King, M.D., et al., 2014. Large mixing ratios of atmospheric nitrous acid (HONO) at Concordia (East Antarctic Plateau) in summer: a strong source from surface snow? Atmos. Chem. Phys. 14, 9963-9976.

Li, D.D., Xue, L.K., Wen, L., Wang, X.F., Chen T.S., Mellouki, A., et al., 2018. Characteristics and sources of nitrous acid in an urban atmosphere of northern China: Results from 1-yr continuous observations. Atmos. Environ. 182, 296-306. 
Lu, K.D., Hofzumahaus, A., Holland, F., Bohn, B., Brauers, T., Fuchs, H., et al., 2013. Missing OH source in a suburban environment near Beijing: observed and modelled $\mathrm{OH}$ and $\mathrm{HO}_{2}$ concentrations in summer 2006. Atmos. Chem. Phys.; 13: 1057-1080.

Meusel, H., Kuhn, U., Reiffs, A., Mallik, C., Harder, H., Martinez, M., et al., 2016. Daytime formation of nitrous acid at a coastal remote site in Cyprus indicating a common ground source of atmospheric HONO and NO. Atmos. Chem. Phys. 16, 14475-14493.

Michoud, V., Colomb, A., Borbon, A., Miet, K., Beekmann, M., Camredon, M., et al., 2014. Study of the unknown HONO daytime source at a European suburban site during the MEGAPOLI summer and winter field campaigns. Atmos. Chem. Phys. 14, 2805-2822.

Oswald, R., Behrendt, T., Ermel, M., Wu, D., Su, H., Cheng, Y., et al., 2013. HONO emissions from soil bacteria as a major source of atmospheric reactive nitrogen. Science 341, 1233-1235.

Oswald, R., Ermel, M., Hens, K., Novelli, A., Ouwersloot, H.G., Paasonen, P., et al., 2015. A comparison of HONO budgets for two measurement heights at a field station within the boreal forest in Finland. Atmos. Chem. Phys. 15, 799-813.

Reed, C., Evans, M.J., Crilley, L.R., Bloss, W.J., Sherwen, T., Read, K.A., et al., 2017. Evidence for renoxification in the tropical marine boundary layer. Atmos. Chem. Phys. 17, 4081-4092.

Sörgel, M., Regelin, E., Bozem, H., Diesch, J.M., Drewnick, F., Fischer, H., et al., 2011. Quantification of the unknown HONO daytime source and its relation to $\mathrm{NO}_{2}$. Atmos. Chem. Phys. 11, 1043310447.

Sörgel, M., Trebs, I., Wu, D., Held, A., 2015. A comparison of measured HONO uptake and release with calculated source strengths in a heterogeneous forest environment. Atmos. Chem. Phys. 15, 9237-9251. 
Salgado, M.S., Rossi, M.J., 2002. Flame soot generated under controlled combustion conditions: Heterogeneous reaction of $\mathrm{NO}_{2}$ on hexane soot. INT. J. CHEM. KINET. 34, 620-631.

Spataro, F., Ianniello, A., Salvatori, R., Nardino, M., Esposito, G., 2016. Montagnoli M. Sources of atmospheric nitrous acid (HONO) in the European High Arctic. Rendiconti Lincei 28, 25-33.

Stutz, J., Alicke, Br., Neftel, A., 2002. Nitrous acid formation in the urban atmosphere: Gradient measurements of $\mathrm{NO}_{2}$ and $\mathrm{HONO}$ over grass in Milan, Italy. J. Geophys.Res. 107.

Su, H., Cheng, Y., Oswald, R., Behrendt, T., Trebs, I., 2011. Meixner FX, et al. Soil Nitrite as a Source of Atmospheric HONO and OH Radicals. Science 333, 1616-1618.

Su, H., Cheng, Y.F., Cheng, P., Zhang, Y.H., Dong, S, Zeng, L.M., et al., 2008a. Observation of nighttime nitrous acid (HONO) formation at a non-urban site during PRIDE-PRD2004 in China. Atmos. Environ. 42, 6219-6232.

Su, H., Cheng, Y.F., Shao, M., Gao, D.F., Yu, Z.Y., Zeng, L.M., et al., 2008b. Nitrous acid (HONO) and its daytime sources at a rural site during the 2004 PRIDE-PRD experiment in China. J. Geophys. Res. 113.

Sun, L., Xue, L.K., Wang, T., Gao, J., Ding, A.J., Cooper, O.R., et al., 2016. Significant increase of summertime ozone at Mount Tai in Central Eastern China. Atmos. Chem. Phys. 16, 1063710650.

Tang, Y., An, J., Wang, F., Li, Y., Qu, Y., Chen, Y., et al., 2015, Impacts of an unknown daytime HONO source on the mixing ratio and budget of HONO, and hydroxyl, hydroperoxyl, and organic peroxy radicals, in the coastal regions of China. Atmos. Chem. Phys. 15, 9381-9398.

Večeřa, Z., Mikuška, P., Smolík, J., Eleftheriadis, K., Bryant, C., Colbeck, I., et al., 2007. Shipboard Measurements of Nitrogen Dioxide, Nitrous Acid, Nitric Acid and Ozone in the Eastern 
491

492

493

494

495

496

497

498

499

500

501

502

503

504

505

506

507

Wang, J.Q., Zhang, X.S., Guo, J., Wang, Z.W., Zhang M.G., 2017. Observation of nitrous acid (HONO) in Beijing, China: Seasonal variation, nocturnal formation and daytime budget. Sci. Total Environ. 587-588, 350-359.

Wang, L.W., Wen L., Xu, C.H., Chen, J.M., Wang X.F., Yang L,X., et al., 2015. HONO and its potential source particulate nitrite at an urban site in North China during the cold season. Sci. Total Environ. 538, 93-101.

Wang, X.P., Chen, Y.J., Tian, C.G., Huang, G.P., Fang, Y., Zhang, F., et al., 2014a. Impact of agricultural waste burning in the Shandong Peninsula on carbonaceous aerosols in the Bohai Rim, China. Sci. Total Environ. 481, 311-316.

Wang, X., Wang, T., Yan, C., Tham, Y.J., Xue, L., Xu, Z., et al., 2014b. Large daytime signals of $\mathrm{N}_{2} \mathrm{O}_{5}$ and $\mathrm{NO}_{3}$ inferred at 62 amu in a TD-CIMS: chemical interference or a real atmospheric phenomenon? Atmos. Measure. Tech. 7, 1-12.

Wang, X.F., Wang, W.X., Yang, L.X., Gao, X.M., Nie, W., Yu, Y.C., et al., 2012. The secondary formation of inorganic aerosols in the droplet mode through heterogeneous aqueous reactions under haze conditions. Atmos. Environ. 63, 68-76.

Wojnárovits, L., Takács, E., 2014. Rate coefficients of hydroxyl radical reactions with pesticide molecules and related compounds: A review. Rad. Phy. Chem. 96, 120-134.

Wojtal, P., Halla, J.D., McLaren, R., 2011, Pseudo steady states of HONO measured in the nocturnal marine boundary layer: a conceptual model for HONO formation on aqueous surfaces. Atmos. Chem. Phys. 11, 3243-3261.

Xu, Z., Wang, T., Wu, J.Q., Xue, L.K., Chan, J., Zha, Q.Z., et al., 2015. Nitrous acid (HONO) in a polluted 
subtropical atmosphere: Seasonal variability, direct vehicle emissions and heterogeneous production at ground surface. Atmos. Environ. 106, 100-109.

Xue, L.K., Wang, T., Gao, J., Ding, A.J., Zhou, X.H., Blake, D.R., et al., 2014. Ground-level ozone in four Chinese cities: precursors, regional transport and heterogeneous processes. Atmos. Chem. Phys. 14, 13175-13188.

Yang, W., Han, C., Yang, H., Xue, X., 2018. Significant HONO formation by the photolysis of nitrates in the presence of humic acids. Environ. Pollut. 243, 679-686.

Zha, Q.Z., Xue, L.K., Wang, T., Xu, Z., Yeung. C.P., Louie, P.K.L., et al., 2014. Large conversion rates of $\mathrm{NO}_{2}$ to $\mathrm{HNO}_{2}$ observed in air masses from the South China Sea: Evidence of strong production at sea surface? Geophy. Res. Lett. 41, 7710-7715.

Zhang, JM., Yang, L.X., Mellouki, A., Wen, L., Yang, Y.M., Gao, Y., et al., 2016. Chemical characteristics and influence of continental outflow on $\mathrm{PM}_{1.0}, \mathrm{PM}_{2.5}$ and $\mathrm{PM}_{10}$ measured at Tuoji island in the Bohai Sea. Sci. Total Environ. 573, 699-706.

Zhang. W.Q., Tong. S.R., Ge, M.F., An, J.L. Shi, Z.B., Hou, S.Q. et al., 2019. Variations and sources of nitrous acid (HONO) during a severe pollution episode in Beijing in winter 2016. Sci. Total Environ. 648, 253-262.

Zhou, X.L., Zhang, N., Michaela, T.A., Tang, D., Hou, J., Bertman, S., et al., 2011. Nitric acid photolysis on forest canopy surface as a source for tropospheric nitrous acid. Nature Geoscience 4, 440443. 
533 Table 1. Statistics of ambient concentrations of HONO, other trace gases, and meteorological 534 parameters during the measurement periods (average \pm standard deviation). The T-test was 535 performed for the difference between the two periods.

\begin{tabular}{llllc}
\hline Species & Full data & $5^{\text {th }}-21^{\text {st }}$ Oct. & $22^{\text {nd }}$ Oct. $-5^{\text {th }}$ Nov. & T-test \\
\hline $\mathrm{HONO}(\mathrm{ppbv})$ & $0.20 \pm 0.20$ & $0.27 \pm 0.23$ & $0.13 \pm 0.11$ & $p<0.01$ \\
$\mathrm{NO}(\mathrm{ppbv})$ & $0.5 \pm 0.7$ & $0.5 \pm 0.5$ & $0.6 \pm 0.8$ & $p=0.32$ \\
$\mathrm{NO}_{2}(\mathrm{ppbv})$ & $5.3 \pm 4.1$ & $4.8 \pm 3.3$ & $5.9 \pm 4.7$ & $p<0.01$ \\
$\mathrm{HONO} / \mathrm{NO}_{\mathrm{x}}$ & $0.040 \pm 0.041$ & $0.057 \pm 0.050$ & $0.021 \pm 0.014$ & $p<0.01$ \\
$\mathrm{CO}(\mathrm{ppbv})$ & $482 \pm 270$ & $478 \pm 239$ & $486 \pm 301$ & $p=0.95$ \\
$\mathrm{O}_{3}(\mathrm{ppbv})$ & $40 \pm 14$ & $45 \pm 15$ & $34 \pm 8$ & $p<0.01$ \\
$\mathrm{~T}\left({ }^{\circ} \mathrm{C}\right)$ & $14.2 \pm 3.8$ & $16.8 \pm 1.9$ & $11.3 \pm 3.3$ & $p<0.01$ \\
$\mathrm{RH}(\%)$ & $74 \pm 14$ & $76 \pm 12$ & $71 \pm 16$ & $p<0.01$ \\
$\mathrm{~J}\left(\mathrm{NO}_{2}\right)\left(10^{-3} \mathrm{~s}^{-1}\right)$ & $1.18 \pm 1.77$ & $1.32 \pm 1.95$ & $1.03 \pm 1.57$ & $p<0.05$ \\
$\mathrm{WS}^{\left(m \mathrm{~m} \mathrm{~s}^{-1}\right)}$ & $3.7 \pm 2.9$ & $3.4 \pm 2.2$ & $4.1 \pm 3.5$ & $p<0.01$ \\
\hline
\end{tabular}


Table 2. The increase and conversion rate of HONO and related pollutant concentrations and

538 meteorological parameters during the selected periods for the eight nighttime cases.

\begin{tabular}{llllllll}
\hline Date & Duration & $\triangle \mathrm{HONO}$ & $\mathrm{C}_{\mathrm{HONO}}$ & Avg. HONO & Avg. $\mathrm{NO}_{2}$ & Avg. T & Avg. RH \\
& $(\mathrm{h})$ & $(\mathrm{ppbv})$ & $\left(\mathrm{h}^{-1}\right)$ & $(\mathrm{ppbv})$ & $(\mathrm{ppbv})$ & $\left({ }^{\circ} \mathrm{C}\right)$ & $(\%)$ \\
\hline $6^{\text {th }}$ Oct. & 2.62 & 0.23 & 0.020 & 0.10 & 4.4 & 15.8 & 68 \\
$8^{\text {th }}$ Oct. & 2.80 & 0.15 & 0.028 & 0.06 & 1.9 & 16.8 & 79 \\
$9^{\text {th }}$ Oct. & 3.18 & 0.15 & 0.018 & 0.09 & 2.7 & 14.8 & 74 \\
$13^{\text {rd }}-14^{\text {th }}$ Oct. & 3.33 & 1.07 & 0.036 & 0.41 & 8.8 & 18.8 & 84 \\
$23^{\text {rd }}$ Oct. & 4.98 & 0.25 & 0.006 & 0.24 & 8.9 & 12.6 & 71 \\
$25^{\text {th }}-26^{\text {th }}$ Oct. & 2.68 & 0.18 & 0.016 & 0.19 & 4.2 & 14.1 & 89 \\
$30^{\text {th }}$ Oct. & 3.05 & 0.13 & 0.008 & 0.14 & 4.8 & 14.7 & 54 \\
$3^{\text {rd }}$ Nov. & 3.05 & 0.21 & 0.010 & 0.14 & 7.3 & 14.1 & 72 \\
\hline
\end{tabular}


541 Fig. 1. Maps showing the location of the measurement site on Tuoji Island in eastern Bohai Sea,

542 China. (a) The color is coded with the tropospheric $\mathrm{NO}_{2}$ column density in Oct. 2016

543 (http://www.temis.nl/index.php); (b) the color is coded with the topographic height.

544 Fig. 2. Temporal variations of the measured $\mathrm{HONO}, \mathrm{NO}_{\mathrm{x}}, \mathrm{CO}, \mathrm{O}_{3}, \mathrm{~J}\left(\mathrm{NO}_{2}\right)$ and meteorological 545 parameters during the measurement period from $5^{\text {th }}$ Oct. to $5^{\text {th }}$ Nov., 2016.

546 Fig. 3. Average diurnal patterns of the measured HONO and related parameters for the early period $547\left(5^{\text {th }}-21^{\text {st }}\right.$ Oct., the blue line $)$ and the later period $\left(22^{\text {nd }}\right.$ Oct. $-5^{\text {th }}$ Nov., the red line $)$. The shaded 548 areas indicate standard deviations. The shadow areas indicate the nighttime periods (18:00-6:00).

549 Fig. 4. Time series of the measured HONO and related parameters for the selected eight nocturnal 550 cases on $6^{\text {th }}, 8^{\text {th }}, 9^{\text {th }}, 13^{\text {th }}, 23^{\text {th }}, 25^{\text {th }}, 30^{\text {th }}$ Oct., and $3^{\text {rd }}$ Nov. The shadow areas indicate the periods 551 with continuous increase in $\mathrm{HONO}$ concentrations and $\mathrm{HONO} / \mathrm{NO}_{2}$ ratios.

552 Fig. 5. Time series of the measured HONO and related parameters for the selected four daytime 553 cases on $6^{\text {th }}, 10^{\text {th }}, 14^{\text {th }}$ Oct., and $4^{\text {th }}$ Nov. The shadow areas indicate the PSS periods from 9:00 to $554 \quad 15: 00$.

555 Fig. 6. Scatter plots of the missing production rate of HONO (S(HONO-missing)) against (a) temperature and (b) $\mathrm{J}\left(\mathrm{NO}_{2}\right)$ for all hourly data during the PSS periods.

Fig. 7. The net production rates of $\mathrm{OH}$ radicals from photolysis of $\mathrm{HONO}$ and ozone as well as the ambient temperature in the four selected daytime cases. 


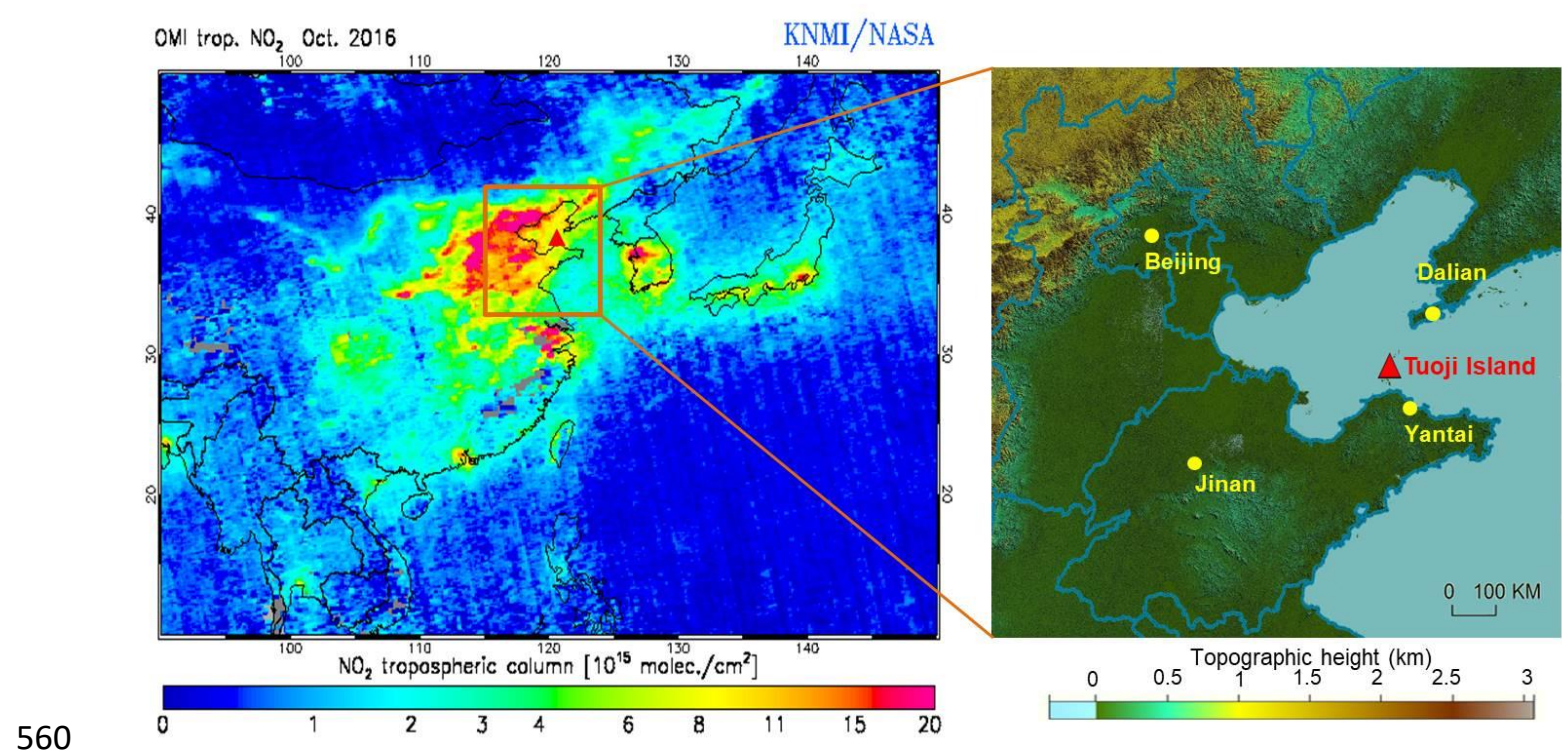

Fig. 1.

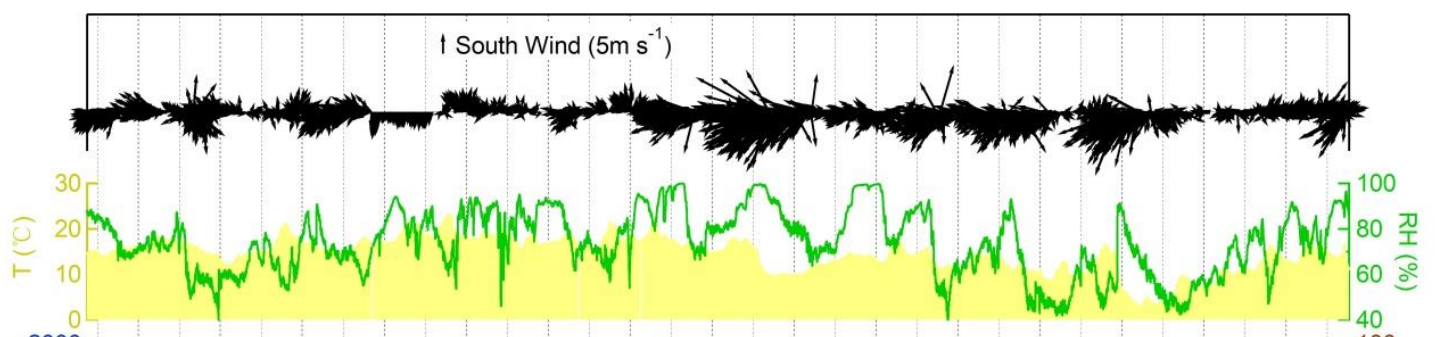

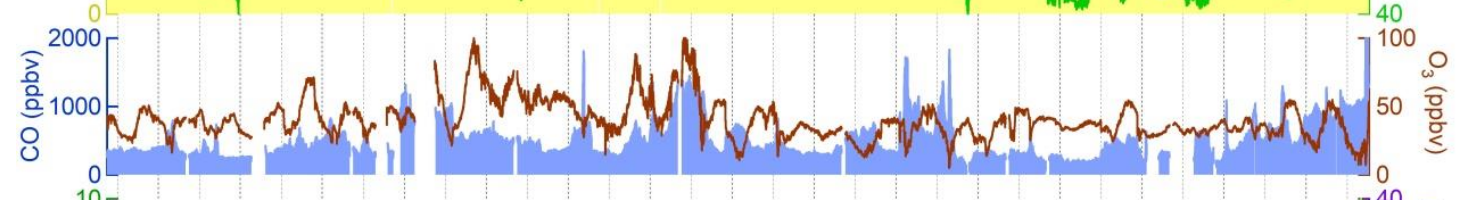

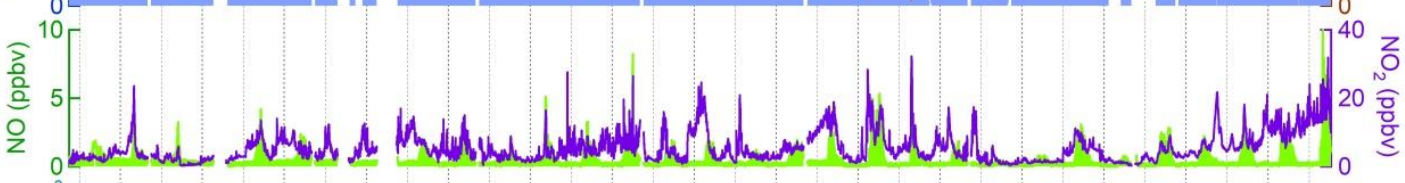
$8 \times 10^{-3}$

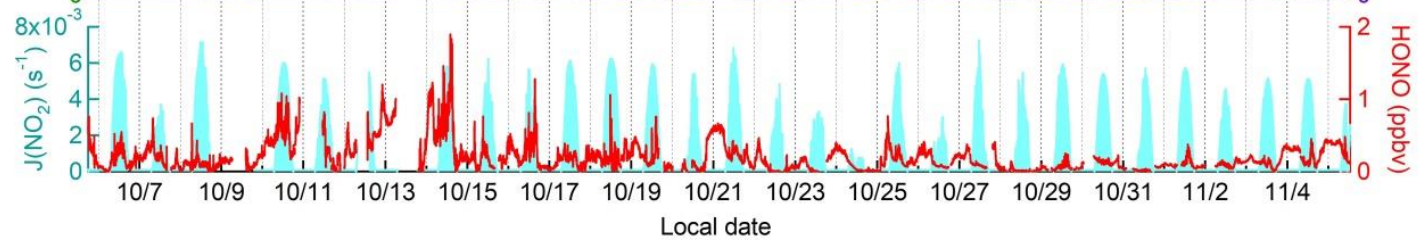

Fig. 2. 


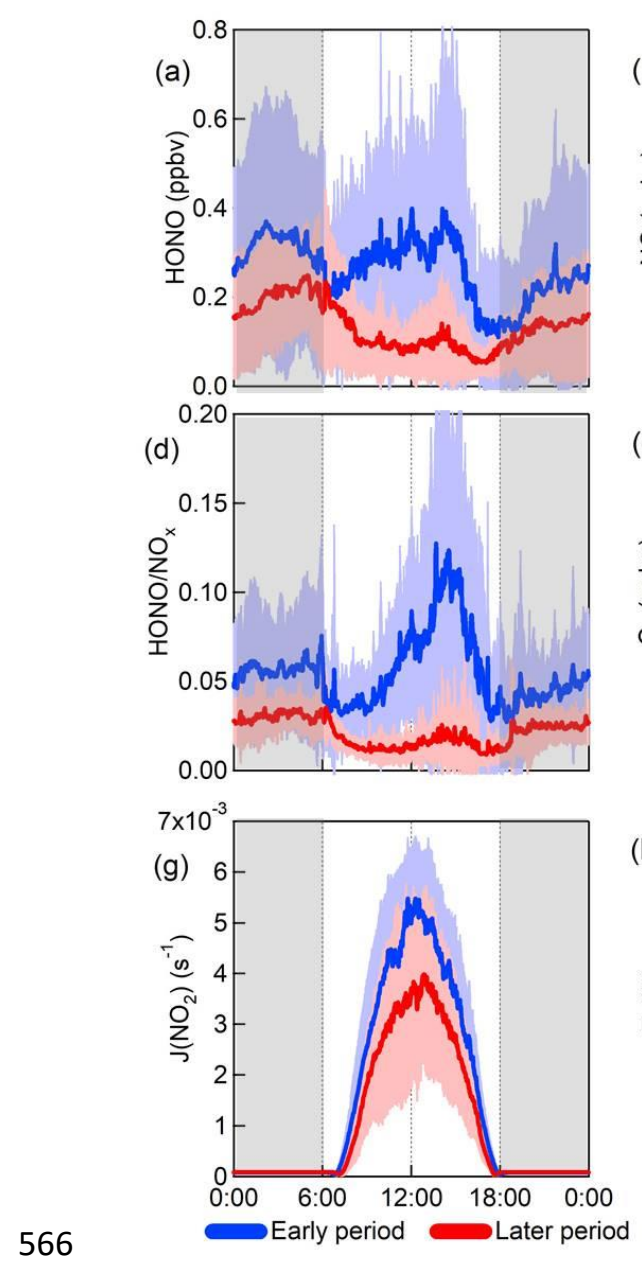

567
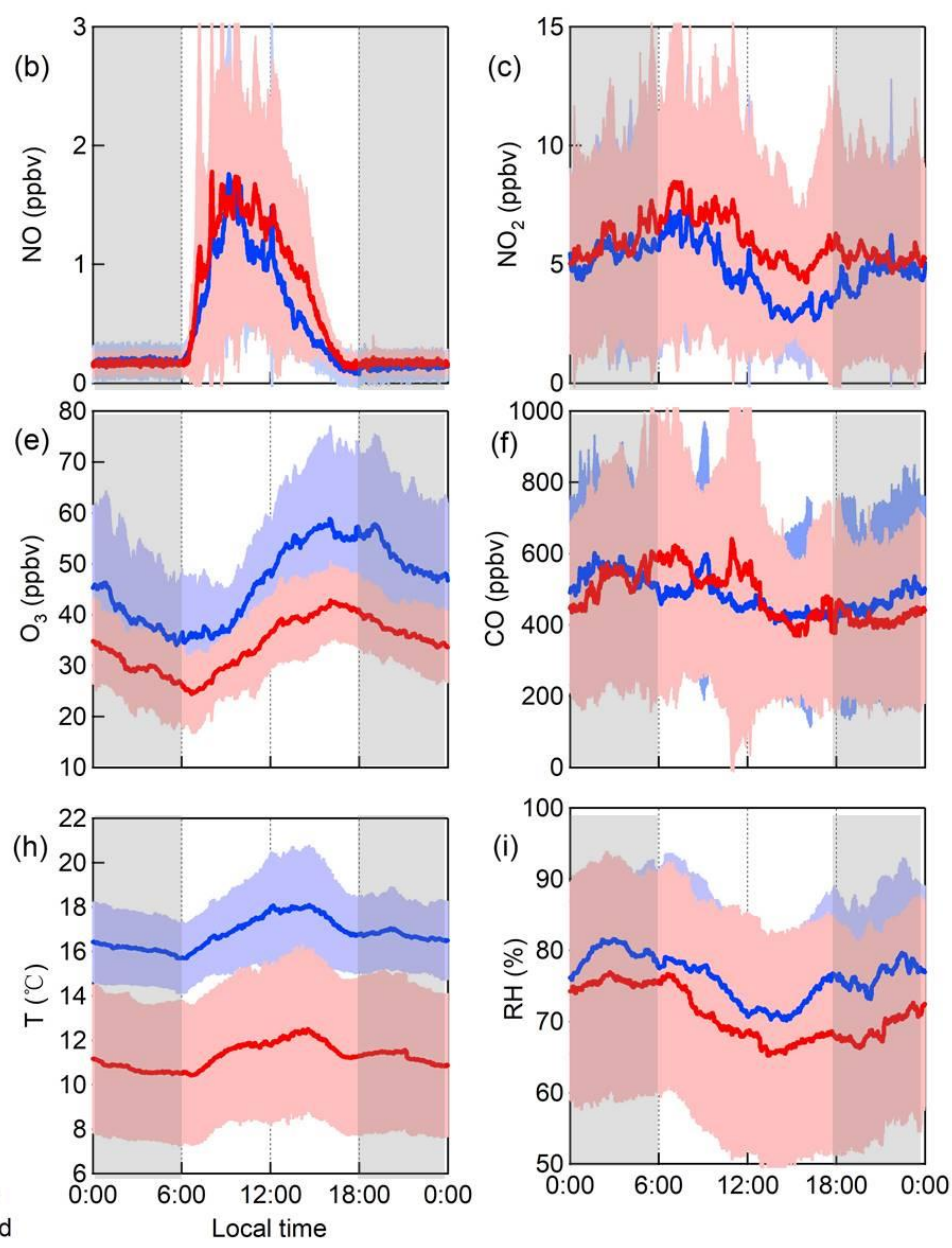

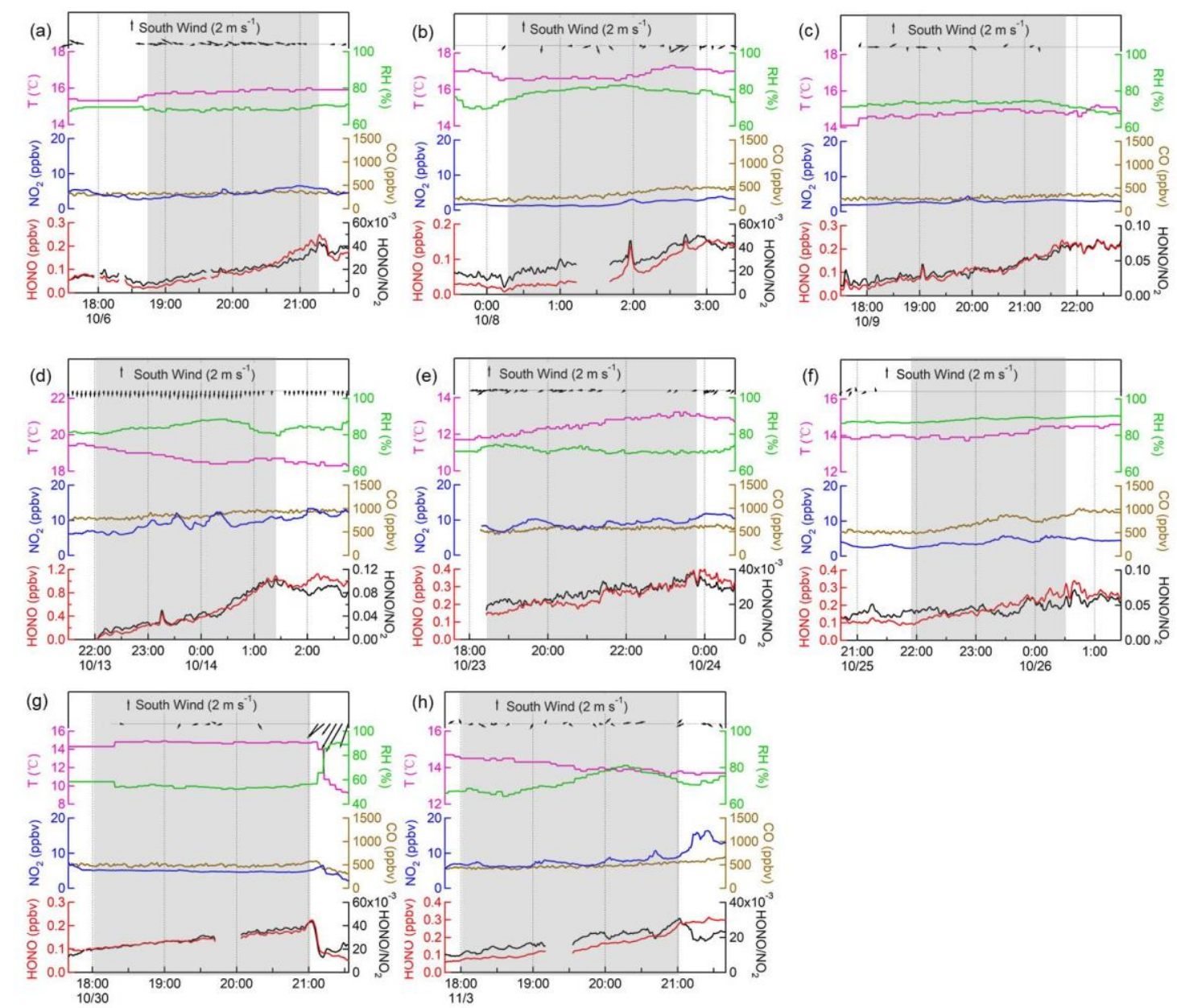

Fig. 4. 

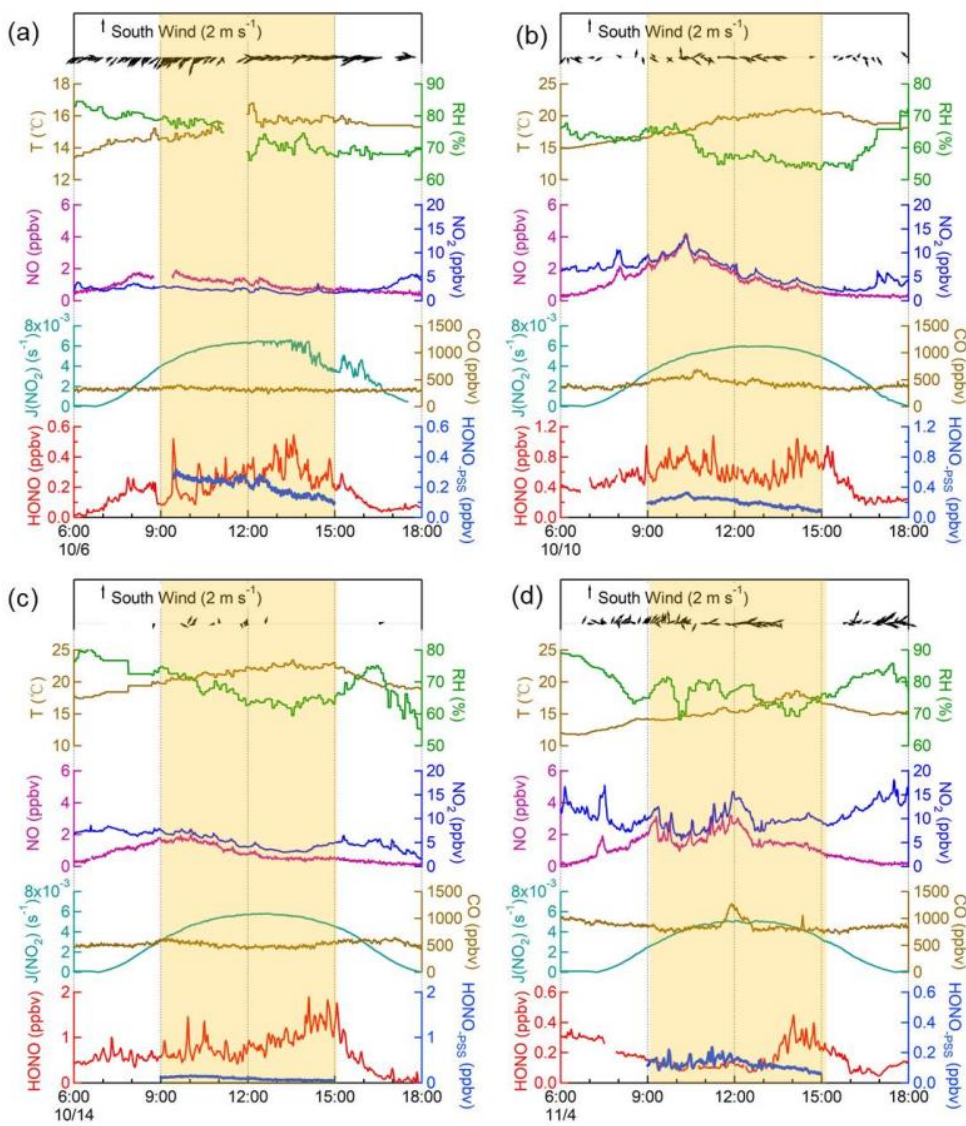

Fig. 5.
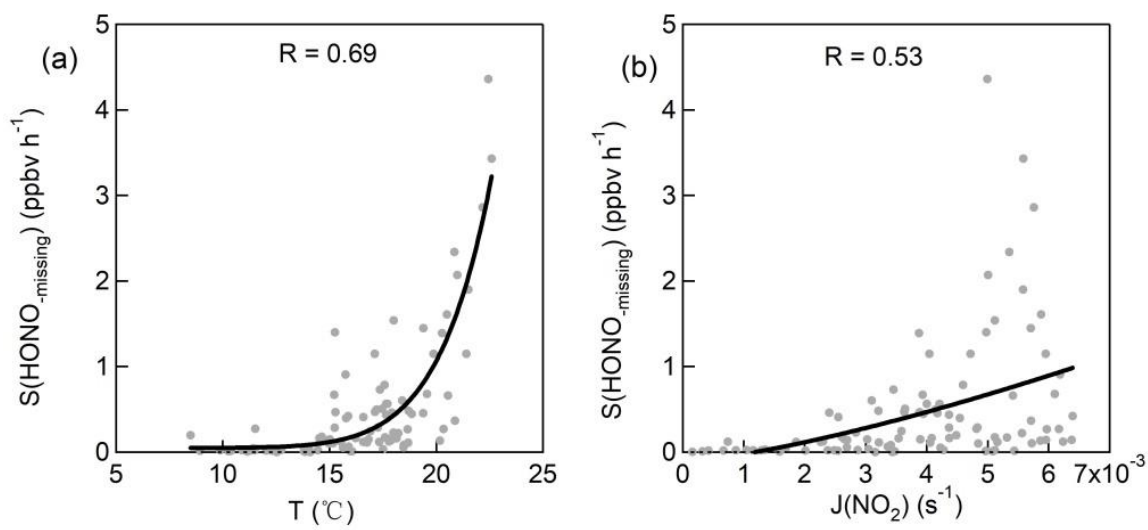

Fig. 6. 

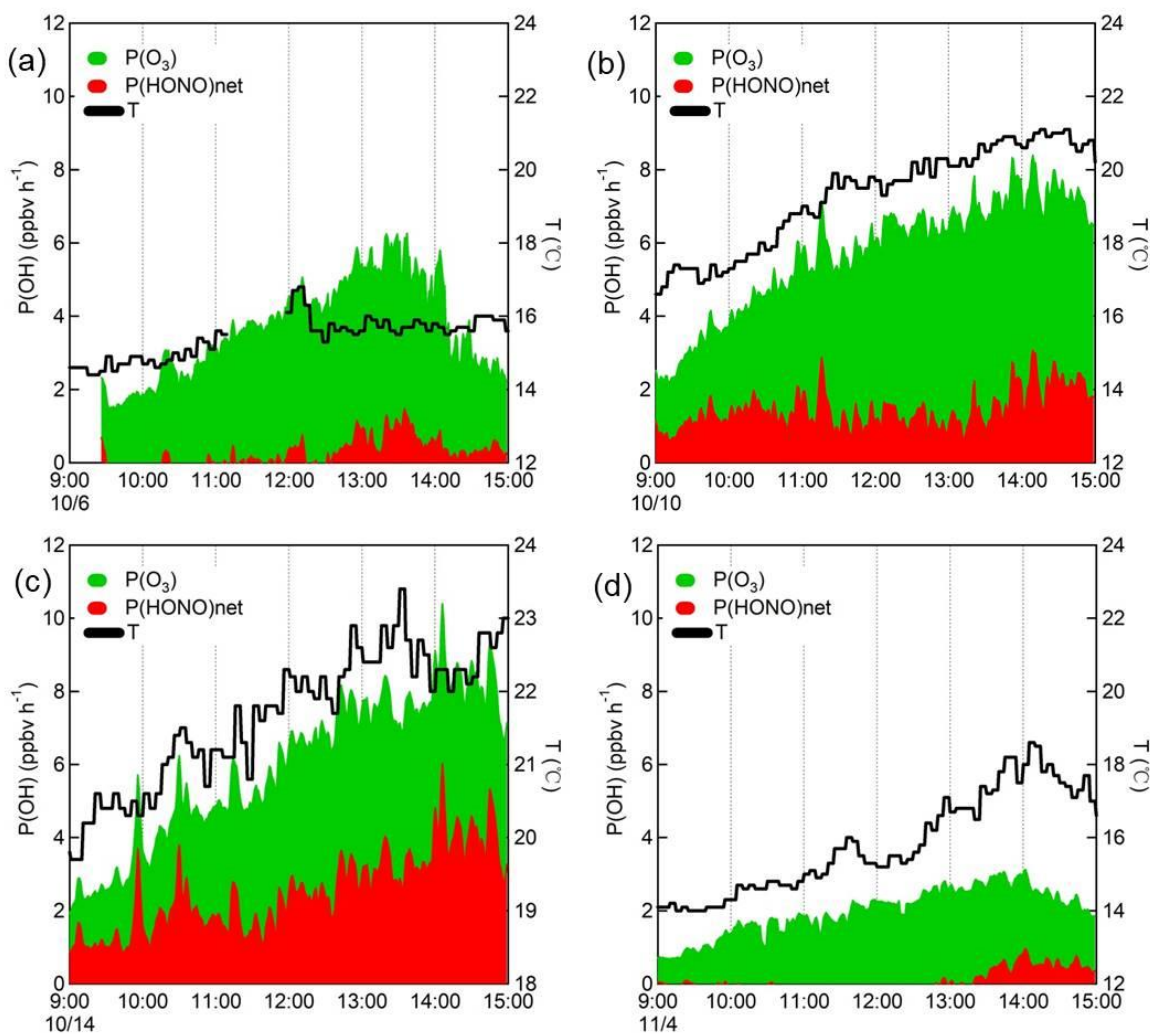

Fig. 7. 